\title{
Effect of shortening the length of codend on brushtooth lizardfish caught in square mesh codend of otter trawl in Eastern Mediterranean
}

\author{
SEVIL DEMIRCI*, ZUBEYIR DOGRU AND EMRAH SIMSEK \\ Iskenderun Technical University, Marine Sciences and Technologies Faculty, Department of Marine Technologies \\ Iskenderun - 31200, Hatay, Turkey \\ e-mail: sevil.demirci@gmail.com
}

\begin{abstract}
This study was done on the use of $40 \mathrm{~mm}$ square mesh codend in otter trawl, the minimum measure in Mediterranean deep trout fishing in Eastern Mediterranean in accordance with European Union (EU) regulations. Brushtooth lizardfish Saurida undosquamis (Richardson, 1848) is an important catch component in this region. The lumen of the square mesh being always open, makes it easy for the fish to escape. However, the fish can sometimes get stuck in the mesh while trying to escape, which can lead to economical loss in commercial fishing. Effect of shortening the length of codend on the rate of entangling of brushtooth lizardfish was assessed. The $8 \mathrm{~m}$ long and $40 \mathrm{~mm}$ square mesh codend was shortened to a length of $4 \mathrm{~m}$. It was observed that shortening the net had no negative impact on the selectivity of the gear and in both cases there was an equal amount of loss and dissatisfaction for the fishermen due to the damage caused while taking out the fish that got entangled in the codend meshes.
\end{abstract}

Keywords: Brushtooth lizardfish, Eastern Mediterranean, Saurida undosquamis, Square mesh codend, Trawl

\section{Introduction}

Trawl fishery is considered to offer lower levels of selectivity in regions with a wide range of species, such as the Mediterranean (Sala, 2008). Thus, selectivity of fishing gears needs to be improved in order to assure sustainable fishery. Recently, several studies have focused on improving selectivity of this fishing method used for exploiting deep sea fish (Aydin and Tosunoglu, 2010; Aydin et al., 2011; Ozbilgin et al., 2011; Aydin et al., 2014; O’Neill et al., 2016). European Union based legal arrangements, suggest the use of square mesh trawl fishing nets with minimum mesh size of $40 \mathrm{~mm}$ and rhombic mesh nets with minimum mesh size of $50 \mathrm{~mm}$ in the Mediterranean (E. C. Council Regulation, 2006). At present, fishers in Turkey comply with the minimum mesh size of square mesh trawl nets but the mesh size of rhombic nets used is $44 \mathrm{~mm}$ (Anon., 2012), However, fishers in the European Union, including Turkey, are known for not preferring square mesh nets. There might be two main reasons underlying the preference of not using square mesh nets although they offer great advantages in terms of selectivity: (i) economic loss due to fishes escaping from the net and (ii) difficulty in making square mesh bags for the nets that are currently in use.

Demirci (2009) has foreseen that using square mesh trawl net can be a specific problem especially at Iskenderun Bay located within the East Mediterranean Fishing Zone.
Brushtooth lizardfish is an important component of trawl landings in this zone. Since the species has fusiform body structure, it can move in the fishing gear and escape through the meshes. The fishes are more likely to get entangled in the square mesh net while escaping, than in the rhombic mesh net and the loss incurred due to damage to the fish while unentangling from the net can often be high, depending on the number and value of the species caught.

The present study was undertaken to test whether the ratio of the brushtooth lizardfish being caught/entangled in the meshes/escaped from the net and selectivity will change if the length of square mesh trawl net is shortened. It is assumed that shortening the square mesh net will have positive impact on the ratio of fishes caught in the net since the number of meshes available for escaping will be reduced. However, there is a possibility that this might have negative impact on selectivity.

\section{Materials and methods}

Trawl trials were conducted offshore in the Iskenderun Bay in East Mediterranean (Fig. 1). The area covered is the legal trawl fishing area and it is very close to Iskenderun fishing port. This zone is preferred due to diversity in catch composition, sea bottom suitable for trawling (smooth-sandy sea bottom) and its closeness to the port. The depth in the area varies between 45 and $70 \mathrm{~m}$. 


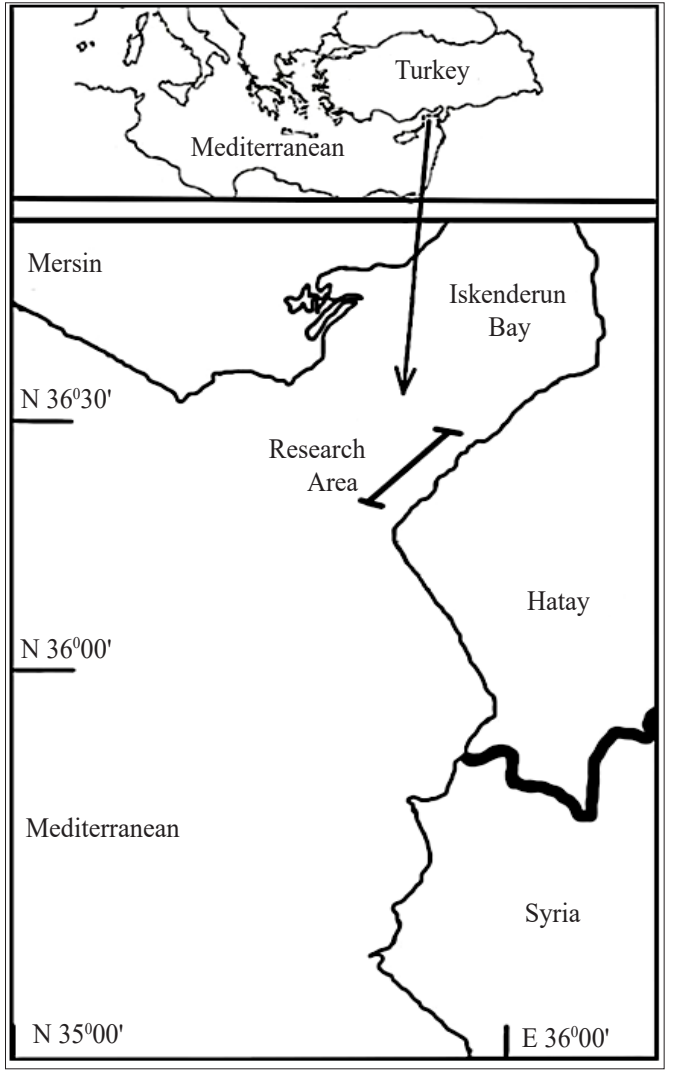

Fig. 1. Study area in the Iskenderun Bay

A commercial trawler Ali Kaptan 6 of 22.3 m length and $450 \mathrm{BG}$ main engine having an auxiliary engine of 150 BG for capstan was used for the study. The capstan used was $1821 \mathrm{~m}$ long having steel ropes of $12 \mathrm{~mm}$ dia. Trawler doors used were $190 \times 90 \mathrm{~cm}$, made of wooden and iron material weighing $130 \mathrm{~kg}$. Sweep lines having $182 \mathrm{~m}$ length with diameters of $22 \mathrm{~mm}$ to $32 \mathrm{~mm}$ were used for the trial. Trawl net used was the traditional East Mediterranean sea bottom trawl with 900 meshes. Total length of trawl net was $47 \mathrm{~m}$ having float line of $24 \mathrm{~m}$ and lead line having $28 \mathrm{~m}$ length. Wing section of the net had a mesh size of $110 \mathrm{~mm}$ and the mesh size of shoulder, tunnel and codend was $44 \mathrm{~mm}$.

Two different sizes of trawl codends were used, both with rope thickness of 1240 Rtex and PE webbing of

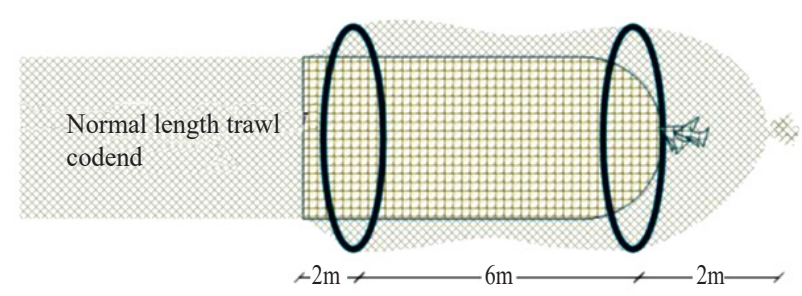

$40 \mathrm{~mm}$ square meshes. Single side cutting (bar) was used for preparing the square mesh codend used for the trial. The codends had a length of $8 \mathrm{~m}$ and perimeter of $4 \mathrm{~m}$. Omega Mesh Gauge was used to measure mesh sizes of codends (Demirci et al., 2012). A total of 60 measurements were taken from 3 different sections of the codend.

Hoops used to avoid cover codend being caught in the net were made with $6 \mathrm{~m}$ length PVC $\varnothing 25$ pipes. These pipes had a standard length of $4 \mathrm{~m}$ and the hoops were made with 1.5 long welding work. Hoops positioned on the cover codend gave a tube-like shape to the net. This provided a large area where fish falling out of trial codend were collected. The cover was fixed $2 \mathrm{~m}$ behind the point of fixing codend. Besides, the cover was positioned on the tunnel section of trawl net and thus it was in front of the codend (Fig. 2).

Trawl operations were performed by the crew and on the same line and the operations were monitored. Dates and coordinates of trawling operations carried out were recorded. Hourly trials were performed with a speed range of 2.3 to 2.5 knots. Time of start and ending of each operation and depth data were recorded. The reeling period was determined as the time passed from positioning the trawl on the sea bottom (tightening the trawler crane) until start of hauling back. In case of an unexpected incident occurring during the operation (damaged trial and cover codend, large scale/unwanted materials in the codend), the relevant operation was cancelled.

The cover codend was opened in one section of the trawler after trawling operation and then trawl bag was opened in another section onboard and were analysed separately. Brushtooth lizardfish caught in the codend were sized and length-weight data were recorded. Fishes inside the codend were recorded as those caught, the ones in the cover were recorded as escaped and the ones that got entangled in the meshes were recorded as stuck. Ratio of fishes caught was examined for each haul in terms of number and weight. Pearson's chi-square test was used to determine whether or not there was a significant difference between normal and short codend (Sarda et al., 2006). Microsoft Office Excel and SPSS package programs were used for analysis.

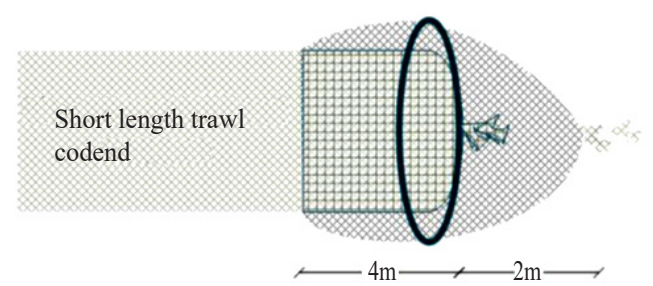

Fig. 2. Diagrammatic representation of normal and short square mesh trawl codends used for experiments 
Logic selectivity model was used for examining whether shortening codend length had any impact on selectivity. Accordingly, $\mathrm{L}_{50}$ selection length and $\mathrm{SR}$ selection interval were calculated for each trawl hauled. Proc NL Mixed Analysis was performed by taking into consideration variations between trawls hauled and selectivity parameters for trawl codends of different sizes. Microsoft Excel handler and SAS package programs were used for analysis (Millar, 2004).

\section{Results and discussion}

Quantity of commercial species caught in normal and short codends is given in Table 1. It is clear that the

Table 1. Quantity of commercial species caught in normal length (NLC) and short length (SLC) codends

\begin{tabular}{lll}
\hline \multirow{2}{*}{ Species } & \multicolumn{2}{c}{ Total catch $(\mathrm{kg})$} \\
\cline { 2 - 3 } & NLC & SLC \\
\hline Saurida undosquamis & 112.35 & 58.9 \\
Sparus aurata & 68.15 & 52 \\
Pagrus pagrus & 22 & 12 \\
Nemipterus randalli & 85.6 & 64.6 \\
Trachurus trachurus & 2 & 2 \\
Loligo vulgaris & 10 & 5.4 \\
Mullus barbatus & 113.7 & 78.5 \\
Penaeus semisulcatus & 6 & 3.5 \\
Total & 419.8 & 276.9 \\
\hline
\end{tabular}

share of species having economic value within the species caught were not the same. Although the number of species caught was high, only one fish species stands out among the fishes that got stuck in the meshes. It was observed that majority of species that got entangled in the trawl codend mesh was brushtooth lizardfish and there were hardly any other species that got entangled in the meshes. Since the situation with other species was not significant, those were not taken into consideration and only data obtained for brushtooth lizardfish was tabulated (Table 2). The high incidence of the brushtooth lizardish getting entangled in the trawl codend mesh could be attributed to the fusiform body structure of the species. Images of brushtooth lizardfish stuck in square meshes were captured both onboard and using underwater trawl camera (Fig. 3).

Fig. 4 and 5 depict the length of brushtooth lizardfish caught using normal codend and short codend respectively. The lowest length of fish caught using both codends were found to be the same but the fishes caught in the short codend were found to have comparatively shorter lengths. It is assumed that this difference was caused by previous hauling operation in the same line using normal codend during which the larger fishes in the population were caught leading to an overall decrease in the length distribution of the population. This reduced the number of fishes larger than approximately $22 \mathrm{~cm}$ total length.

Table 2. Haul-wise data on number and weight of brushtooth lizardfish caught, escaped and stuck in normal and short trawl codend types (TCT)

\begin{tabular}{|c|c|c|c|c|c|c|c|}
\hline \multirow{2}{*}{ TCT } & & \multicolumn{2}{|c|}{ Catch } & \multicolumn{2}{|c|}{ Escape } & \multicolumn{2}{|c|}{ Stuck } \\
\hline & & Number & Weight $(\mathrm{kg})$ & Number & Weight (kg) & Number & Weight $(\mathrm{kg})$ \\
\hline \multirow{9}{*}{ Normal } & 1 & 110 & 12 & 16 & 1.76 & 6 & 0.65 \\
\hline & 2 & 124 & 13.5 & 21 & 1.89 & 10 & 1.3 \\
\hline & 3 & 194 & 20 & 18 & 1.71 & 9 & 1.2 \\
\hline & 4 & 79 & 10.5 & 15 & 1.35 & 7 & 0.7 \\
\hline & 5 & 139 & 14.5 & 26 & 2.33 & 10 & 1.0 \\
\hline & 6 & 130 & 14 & 27 & 2.16 & 8 & 0.9 \\
\hline & 7 & 96 & 11.25 & 19 & 1.63 & 11 & 1.3 \\
\hline & 8 & 70 & 8.2 & 44 & 3.47 & 17 & 1.8 \\
\hline & 9 & 67 & 8.4 & 59 & 4.42 & 17 & 1.9 \\
\hline \multicolumn{2}{|l|}{ Mean } & 112.11 & 112.35 & 27.22 & 2.30 & 10.56 & 10.75 \\
\hline \multirow{8}{*}{ Short } & 1 & 71 & 8.5 & 17 & 1.46 & 10 & 1.2 \\
\hline & 2 & 65 & 6.5 & 12 & 1.08 & 5 & 0.6 \\
\hline & 3 & 55 & 6.5 & 10 & 0.95 & 4 & 0.5 \\
\hline & 4 & 44 & 5.5 & 5 & 0.46 & 5 & 0.5 \\
\hline & 5 & 117 & 11.2 & 11 & 0.97 & 3 & 0.45 \\
\hline & 6 & 108 & 10.5 & 17 & 1.42 & 9 & 1.1 \\
\hline & 7 & 69 & 5.7 & 19 & 1.44 & 5 & 0.65 \\
\hline & 8 & 49 & 4.5 & 8 & 0.71 & 6 & 0.7 \\
\hline Mean & & 72.25 & 58.9 & 12.38 & 1.06 & 5.88 & 5.7 \\
\hline
\end{tabular}




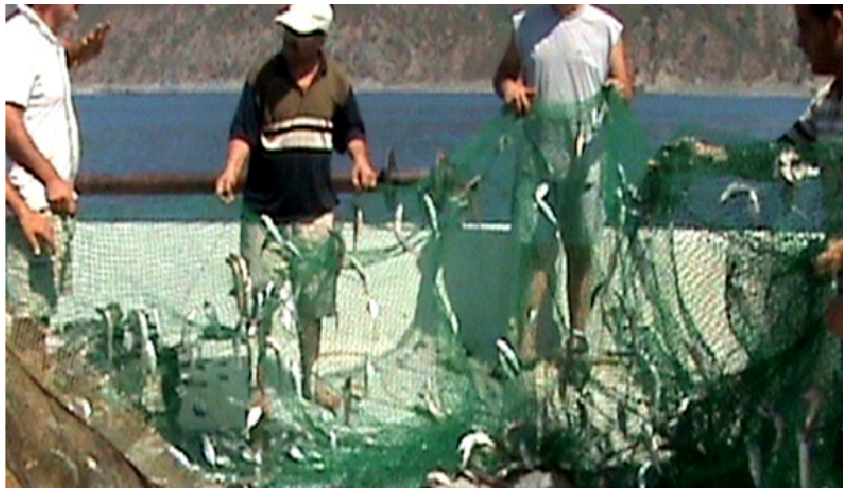

(a)

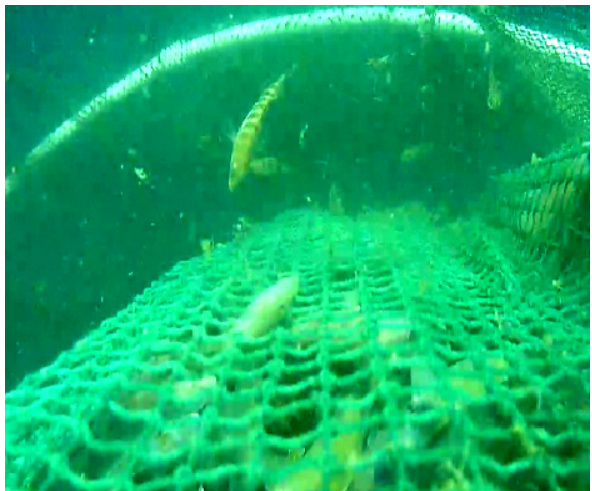

(b)

Fig. 3. Brushtooth lizardfish stuck in square meshes of trawl codend a: onboard vessel, b: underwater

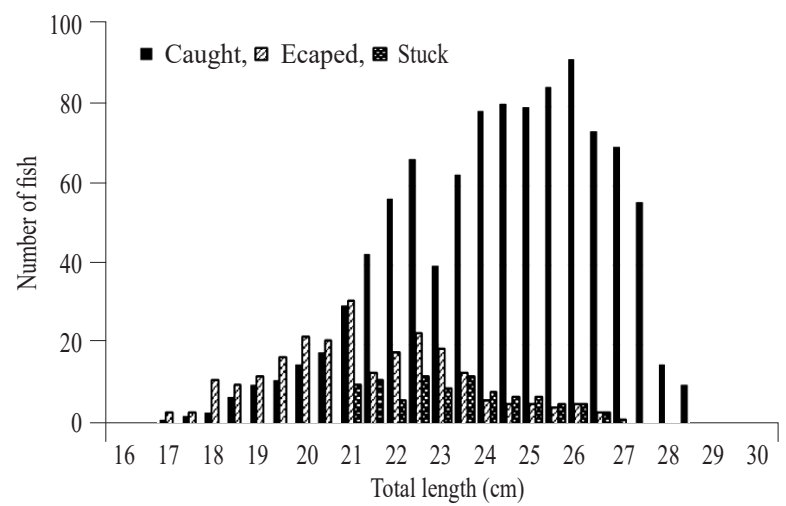

Fig. 4. Length frequency of brushtooth lizardfish caught with normal trawl bag

Table 3 details the averages and comparisons of fishes caught escaped and stuck in short and normal size trawl codends. The average number of fishes in the normal size trawl codend was 112.11, while in the short codend it was 72.25. The average numbers of fishes escaped were 27.22 and 12.38 respectively, while the average numbers of fishes that got stuck were 10.56 and 5.88 respectively. Also, the normal size trawl codend caught 149.89 fishes per haul on an average and the short size codend caught 90.50. The difference in results were not found to be statistically significant when assessed using Pearson's chi-square test.

In selectivity studies, difference caused by uncontrollable variables between hauls had to be considered and therefore the $\mathrm{L}_{50}$ values of the codends were determined by PROC-NL Mixed Analysis which addressed the quantity of catch which has the most important difference between hauls. The $\mathrm{L}_{50}$ value was 18.41 for ordinary codends and 18.50 for short codends whereas SR value was 4.62 for ordinary codend and 3.76 for short codend (Table 4).

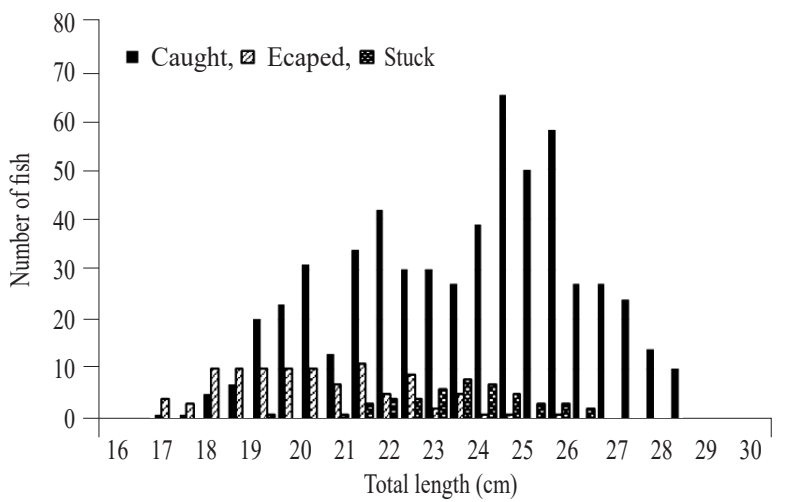

Fig. 5. Length frequency of brushtooth lizardfish caught with short trawl bag

Brushtooth lizardfish escaped and caught had similar characteristics in both codend lengths because the size of fishes escaped and caught were actually related to the mesh size. Similar results obtained with the same mesh size verify that shortening the codend length did not have significant impact. From Table 2, it is clear that there were more fishes caught in the normal codend.This might be due to various reasons. First of all, trawls were towed on the same line, first with normal codend and then with shorter codend. This might have reduced the fish stock in the area during towing of short codend net. Secondly, we might assume that shortening the codend, made escape harder for the fishes. Wileman et al.(1996) argued that this can be explained with the fullness of catch in the trawl codend. Fishes in the trawl codend have limited space to move around and this limitation reduces the number of fishes trying to escape as well as number of fishes caught in the codend while trying to escape. The difference between the number of fishes in the ordinary and short codend is evident in Table 2. Conducting a similar study at the beginning of the fishing season and studying related data might clarify this matter as there would be sufficient 
Table 3. Number, mean length and weight of brushtooth lizardfish caught, escaped and stuck in short $(\mathrm{S})$ and normal $(\mathrm{N})$ trawl codend types (TCT) $(\mathrm{p}>0.05)$

\begin{tabular}{|c|c|c|}
\hline Catch & Mean & TCT \\
\hline \multicolumn{3}{|c|}{ Number of fish } \\
\hline \multirow[t]{2}{*}{ Caught } & $112.11 \pm 13.47$ & $(\mathrm{~N})$ \\
\hline & $72.25 \pm 9.43$ & (S) \\
\hline \multirow[t]{2}{*}{ Escaped } & $27.22 \pm 4.94$ & $(\mathrm{~N})$ \\
\hline & $12.38 \pm 1.73$ & (S) \\
\hline \multirow[t]{2}{*}{ Stuck } & $10.56 \pm 1.32$ & $(\mathrm{~N})$ \\
\hline & $5.88 \pm 0.85$ & (S) \\
\hline \multirow[t]{2}{*}{ Total } & $149.89 \pm 11.56$ & $(\mathrm{~N})$ \\
\hline & $90.50 \pm 10.54$ & (S) \\
\hline \multicolumn{3}{|c|}{ Mean length $(\mathrm{cm})$} \\
\hline \multirow[t]{2}{*}{ Caught } & $23.97 \pm 0.31$ & $(\mathrm{~N})$ \\
\hline & $22.99 \pm 0.41$ & (S) \\
\hline \multirow[t]{2}{*}{ Escaped } & $20.81 \pm 0.36$ & $(\mathrm{~N})$ \\
\hline & $19.45 \pm 0.24$ & (S) \\
\hline \multirow[t]{2}{*}{ Stuck } & $22.74 \pm 0.24$ & $(\mathrm{~N})$ \\
\hline & $22.56 \pm 0.26$ & (S) \\
\hline \multicolumn{3}{|c|}{ Weight (kg) } \\
\hline \multirow[t]{2}{*}{ Weight } & $12.48 \pm 1.21$ & $(\mathrm{~N})$ \\
\hline & $7.36 \pm 0.86$ & (S) \\
\hline
\end{tabular}

Table 4. $\mathrm{L}_{50}$ and SR values of Brushtooth lizardfish for normal and short trawl bags

\begin{tabular}{lllll}
\hline Trawl codend & $\mathrm{L}_{50}$ & VarL $_{50}$ & $\mathrm{SR}$ & VarSR \\
\hline Normal & 18.41 & 1.76 & 4.62 & 1.60 \\
Short & 18.50 & 2.14 & 3.76 & 2.42 \\
\hline
\end{tabular}

fish stock available. Controllable variables were kept as stable as possible throughout the study in order to obtain reliable data. However, the differences due to natural causes cannot be avoided.

As detailed in Table 3, the lengths of brushtooth lizardfish caught, escaped and stuck are similar to each other. The decrease in fishes escaped and caught could be attributed to the average length of the population. In order to minimise the number of fishes stuck in codend meshes without having a negative impact on selectivity features, the relationship between the size of fish body and inner circle of the codend mesh can be applied (Liang et al., 1999). Fishes with bodies (largest point of body) smaller than $80 \mathrm{~mm}$ will have a chance to escape from the square mesh codend of $40 \mathrm{~mm}$ mesh size. Besides, since the species discussed here feeds on other fishes, those with a full stomach get stuck in the meshes and then cannot escape from the net because its body cannot pass through the mesh, although the head can. Demirci (2009) and Ozbilgin et al. (2015) reported lower values of $\mathrm{L}_{50}$ selectivity (22.5 and 24.1 respectively) in the same square mesh trawl codend for this fish. The difference in the present study could be due to higher thickness of twine used in the codend.

As the fishes in both codends were found to have similar lengths and the selectivity values were very close to each other, it can be concluded that there is no significant difference between the lengths of fishes caught in the codend. Also when using square mesh codends in Iskenderun Bay for brushtooth lizardfish, the length of the codend does not impact the ratio of fishes caught, escaped and those got stuck in the meshes.

\section{Acknowledgements}

Authors thank BAP Foundation of Mustafa Kemal University for their financial support.

\section{References}

Anon. 2012. Commercial Fisheries Regulating Hunting Notification (Notification no: 2012/65), 18 August 2012 and 28388 Official Gazette, Food, Agriculture and Livestock Ministry 3/1 (In Turkish).

Aydin, C. and Tosunoglu, Z. 2010. Selectivity of diamond, square and hexagonal mesh codends for Atlantic horse mackerel Trachurus trachurus, European hake Merluccius merluccius and greater forkbeard Phycis blennoides in the eastern Mediterranean. J. Appl. Ichthyol., 26: 71-77.

Aydin, C., Sensurat, T., Qzdemir, Y. and Tosunoglu, Z. 2014. Effect of the number of meshes in the protective bag circumference on size selectivity of demersal trawl codends. J. Appl. Ichthyol., 30: 454-462.

Aydin, C., Tokac, A., Ulas, A., Maktay, B. and Sensurat, T. 2011. Selectivity of $40 \mathrm{~mm}$ square and $50 \mathrm{~mm}$ diamond mesh codends for five species in the Eastern Mediterranean demersal trawl fishery. Afr. J. Biotechnol., 10(25): 5037-5047.

Demirci, S, 2009. Size selectivity of square and diamond mesh trawl codend for fish with different body shapes. (In Turkish). Ph.D. thesis. Mustafa Kemal University. Hatay, 101 pp.

Demirci, A., Demirci, S. and Simsek, E. 2012. Measurement techniques and challenges of net mesh size in fisheries. (In Turkish). In: Proceedings of the IX. National Turkey's Coastal and Marine Areas Congress, November 2012, Hatay-Turkey, p. 453-459.

E.C. Council Regulation NO 1967/2006, 2006. Concerning management measures for the sustainable exploitation of fishery resources in the Mediterranean Sea, Amending Regulation (EEC) No 2847/93 and repealing Regulation (E.C.) No 1626/94.

Liang, Z., Horikawa, H., Tokimura, M. and Tokai, T. 1999. Effect of cross-sectional shape of fish body on mesh selectivity of trawl codend. Nippon Suisan. Gakk., 65: 441-447. 
Millar, R. B. 2004. Simulated maximum likelihood applied to non-gaussian and nonlinear mixed effects and state-space models. Aust. Nz. J. Stat., 46(4): 543-554.

O’Neill, F. G., Kynoch, R. J., Blackadder, L., Fryer, R. J., Eryaşar, A. R., Notti, E. and Sala, A. 2016. The influence of twine tenacity, thickness and bending stiffness on codend selectivity. Fish. Res., 176: 94-99.

Ozbilgin, H., Tosunoglu, Z., Tokac, A. and Metin, G. 2011. Seasonal variation in the trawl codend selectivity of red mullet (Mullus barbatus). Turk. J. Fish. Aquat. Sci., 11: 191-198.

Ozbilgin, H., Eryaşar, A. R., Gokce, G., Ozbilgin, Y. D., Bozaoglu, A. S., Kalecik, E. and Herrmann, B. 2015. Size selectivity of hand and machine woven codends and short term commercial loss in the North-eastern Mediterranean. Fish. Res., 164: 73-85.

Sala, A. 2008. Size selection by diamond and square-mesh codends in multi-species Mediterranean demersal trawl fisheries. Fish. Res., 93: 8-21.

Sarda, F., Bahamon, N., Moli, B. and Sarda-Palomera, F. 2006. The use of a square mesh codend and sorting grids to reduce catches of young fish and improve sustainability in a multispecies bottom trawl fishery in the Mediterranean. Sci. Mar., 70(3): 347-353.

Wileman, D. A., Ferro, R. S. T., Fonteyne, R. and Millar, R. B. 1996. Manual of methods of measuring the selectivity of towed fishing gears. ICES Cooperative Research Report No. 215, 126pp 